\title{
Vermikompos Sebagai Media Tanaman Sirih Dalam Pot Ban Bekas Motor (BBM) Untuk Kegiatan Alternatif Pada Era Ketidakpastian Bagi Klaster Komoditas Warung Jajanan KKWJ Di Sekitar Universitas Bengkulu
}

Redy Badrudin ${ }^{1}$,Ketut Sukiyono ${ }^{2}$, Gita Mulyasari ${ }^{3}$

${ }^{123}$ Jurusan Sosial Ekonomi Pertanian Fakultas Pertanian Universitas Bengkulu E-mail: redybd11@gmail.com

\begin{tabular}{ll}
\hline Article History: & Abstrak: \\
Received: Mei 2021 & Pengabdian masyarakat klaster warung \\
Revised: Juni 2021 & jajanan (HSCC) di sekitar Universitas \\
Accepted: Juni 2021 & Bengkulu (UNIB) ini bertujuan untuk \\
Available online: Juni & meningkatkan tingkat kognitif, sikap, dan \\
2021 & keterampilan produk kascing sebagai media \\
& tanam bethel untuk kelangsungan ekonomi \\
& dan aktivitas tambahan di era pandemi covid- \\
& 19 . Metode yang digunakan adalah \\
Kata Kunci: & pembelajaran online (slide oral), video, dan \\
alternatif, bethel, BBM- & diskusi. Output dari kegiatan ini ditunjukkan \\
POT, alternatif, HSCC, & dengan kehadiran peserta 100\%, 12 peserta, \\
kascing & dan hasil pretest dan posttest yaitu \\
& "meningkat" kognitif, sikap, dan keterampilan \\
& dalam membuat kascing sebagai pupuk \\
& organik menggunakan BBM-pot. Evaluasi \\
& kegiatan ini dikategorikan "sangat berhasil" \\
untuk meningkatkan kemampuan kognitif dan \\
"berhasil" untuk meningkatkan sikap dan \\
keterampilan.
\end{tabular}




\section{Pendahuluan}

Pengeluaran untuk konsumsi rumah tangga ikut mengalami penurunan selama tahun 2020 akibat pandemi covid-19 di Provinsi Bengkulu. Penurunan ini dibuktikan dengan laju pertumbuhan PDRB pada komponen konsumsi remah tangga berkontraksi secara y-on-y pada kuartal dua sampai empat berturut-turut sebanyak $-0,48$ persen, $-0,74$ persen, dan $-2,20$ persen (BPS, 2020). Adanya penurunan konsumsi rumah tangga diikuti dengan penurunan pendapatan yang disebabkan berbagai restriksi oleh pemerintah untuk mengendalikan pandemi. Hal ini berefek pada melambatnya roda-roda perekonomian dalam sektor informal (Estupinan \& Sharma, 2020).

Sektor infomal terdiri menurut pengertian BPS terdiri atas seseorang yang berusaha untuk mencukupi dirinya, dibantu buruh tetap ataupun tidak tetap, pekerja bebas di sektor pertanian dan non pertanian. Hal ini termasuk para pekerja di sektor usaha mikro dan menengah (UMKM) dan penjualpenjual makanan yang didefinisikan pada tulisan ini sebagai klaster komoditas warung jajanan (KKWJ).

Pekerja sektor informal pada klaster komoditas warung jajanan (KKWJ) dapat melakukan kegiatan pemanfaatan penjualan daun sirih yang pertumbuhannya diakselerasi menggunakan metode vermikompos dalam mengatasi pendapatan yang menurun di sektor informal. Hal ini mempertimbangkan banyaknya manfaat daun sirih dan bahan pembuatan vermikompos yang mudah didapat dan diolah menjadi pupuk tanaman.

Vermikompos adalah jenis pupuk organik yang didapatkan melalui mekanisme sistem pencernaan yang terdapat di perut cacing tanah (Nusantara dkk., 2010). Selain itu, pupuk ini memiliki banyak unsur hara karena juga mengandung unsur kotoran cacing (Putra dkk., 2020). Pemanfataan metode vermikompos dapat meningkatkan kualitas tanah dan hasil tanaman. Hal ini karena pupuk ini mengandung unsur $\mathrm{N}, \mathrm{K}, \mathrm{P}, \mathrm{Ca}$, dan $\mathrm{Mg}$ secara seimbang, terdapat hoormon pertubuhan tanaman, dan kandungan bahan organik (Lazcano \& Domínguez, 2011). Pembuatan metode vermakopos tidak terlalu sulit dengan menggunakan kotoran sapi yang telah diproses dan digabungkan dengan cacing tanah (Brata, 2017). Para peternak sapi dapat memanfaatkan pembuatan vermikompos dengan baik sehingga berpotensi untuk 
mendapatkan pendapatan tambahan. Selain itu dari sisi pemeliharaan tanaman, ini dapat dijadikan salah satu referensi katalis dalam meningkatkan kualitas tanaman.

Pemanfaatan vermikompos didesiminasikan oleh para peneliti, diantaranya: (Mujiyo \& Suryono, n.d.; Suranjaya et al., 2019; Wardana et al., 2017) sebagai salah satu alternatif yang dapat digunakan untuk mengurangi dampak penggunaan pupuk anorganik, upaya dalam menyukseskan "Zero Waste." Hal ini termasuk salah satu cara dalam menanggulangi isu lingkungan. Selain itu, pemanfaatan media tanam yang menggunakan aspek limbah sukar untuk diolah seperti ban bekas motor (BBM) dapat digunakan.

Tanaman yang dipilih dalam penyuluhan adalah sirih. Hal ini dikarenakan tanaman sirih dapat dijadikan alternatif sebagai obat kumur. Manfaat lain dari tanaman ini adalah apabila di rebus memiliki efek bakterisid, antioksidan dan antijamur sehingga dapat digunakan untuk menjaga kesehatan dan mengatasi infeksi ringan rongga mulut (Ariesanti dkk., 2021). Penggunaan tanaman sirih juga dapat mengurangi polutan yang terdapat di lingkungan sekitar rumah (Putrianingsih \& Dewi, 2019).

Dalam rangka membantu meringankan beban pedagang jajanan, kegiatan ini ingin memperkenalkan tanaman sirih sebagai tanaman obat dan potensi usaha sampingan dari vermikompos. Setelah memperkenalkan kegiatan ini, diharapkan peserta kegiatan dapat mempraktikan secara langsung pembuatan vermikompos. Berdasarkan uraian di atas jurnal ini berjudul "Vermikompos Sebagai Media Tanaman Sirih dalam Pot Ban Bekas Motor (BBM) untuk Kegiatan Alternatif pada Era Ketidakpastian Bagi Klaster Komoditas Warung Jajanan (KKWJ) di Sekitar Universitas Bengkulu".

\section{Metode}

Cara mendapatkan kelompok sasaran yang akan disuluh ini melalui penelusuran terhadap pebisnis warung/kedai jajanan di sekitar Universitas Bengkulu (UNIB) sebagai usaha mikro yang berjumlah berkisar 100 padagang yang termasuk kategori usaha mikro ataupun super mikro juga mengalami ketidakpastian bisnis dan perekonomian. Warung/kedai pedagang jajanan di sekitar Unib ini kebanyakan menyewa di sekitar Unib, sedangkan rumah 
tinggalnya/domisilinya menyebar di beberapa kelurahan di Kota Bengkulu.

Dalam berinteraksi, para penjual jajanan ini paling tidak terdapat dua lingkungan. Lingkungan pertama, kebanyakan berinteraksi sesama civitas akademika Universitas Bengkulu, terutama mahasiswa ketika mereka membuka kedainya. Kedua para penjual jajanan ini berinteraksi dengan masyarakat di lingkungan tempat tinggal, terutama sebelah kiri-kanan dan depan rumah mereka. Paling tidak setiap keluarga penjual jajanan di lingkungan pemukimannya berinteraksi inter dan antar keluarga sebanyak lima atau total enam keluarga. Oleh karena itu, pendekatan sasaran merupakan pendekatan klaster komunitas penjual jajanan, keluarga dan tetangganya di daerah domisilinya. Masyarakat sasaran adalah perwakilan keluarga dua pedagang dan perwakilan 10 tetangga lingkungan pedagang, termasuk tiga mahasiswa sebagai representatif dari konsumen, atau total 15 orang sasaran yang merupakan innovator dan early adopter yang selanjutnya mereka diharapkan menjadi agent of change dalam proses difusi innovasi. Harapannya semakin banyak masyarakat sasaran yang paham dan berminat dalam melakukan inovasi vermikompos.

Bahan penyuluhan (paket ipteks) pembuatan vermikompos adalah sebagai berikut;

1. Menyiapkan sejumlah bahan dan peralatan yang akan digunakan dalam Penyuluhan/edukasi On-line

2. Pendampingan untuk meningkatkan pengetahuan, sikap dan keterampilan budidaya Sirih ramah lingkungan dan pemanfaatan daun sirih..

Partisipasi Mitra diharapkan aktif dalam kegiatan dengan tetap taat kepada protokol kesehatan dan kesediaanya melaksanakan kegiatan secara blending, sebagian kegiatan off-line dan sebagian kegiatan on-line.

Slide dan video dibuat sendiri berisikan: Pengenalan vermikompos untuk bahan media tanam Sirih, Pembibitan dan Pemelihraan tanaman Sirih dalam kemasan bekas, dan Pengenalan dan sumulasi pembuatan pot cantik dari 
limbah untuk budidaya Sirih

Tempat dan waktu kegiatan

Kegiatan ini dilaksanakan menggunakan platform zoom meeting, dilanjutkan dengan diskusi yang dilaksanakan bulan 25 Oktober 2020.

Untuk melakukan penyuluhan online agar terjadi pemahaman pemahaman dan minat terhadap inovasi vermikompos dan delapan hari kemudian pad tanggal dua Novemvber 2020 dilakukan kunjungan ke lokasi untuk melihat tamabahan keterampilan dari pembuatan vermikompos. Kesinambungan interaksi antara pelaksana dan audiens terus dijaga dengan membuat grup whatsapp.

\section{Metode}

Pengabdian ini dilaksanakan secara daring yang diawali dengan penyampaian informasi (slide dan video), dan tanya jawab dengan tujuan meningkatkan pemahaman, minat dan keterampilan partisipan tentang pembuatan vermikompos untuk tanaman sirih dalam pot BBM sebagai kegiatan alternatif pada era ketidakpastian bagi $K K W J$ di sekitar unib..

Pembuatan vermikompos adalah sebagai berikut (1) Cacing tanah yang digunakan untuk setiap perlakuan sebanyak 30 ekor, cacing tanah yang digunakan berasal dari hasil budi daya budi daya dan pemeliharaan dan (2) Media cacing tanah hasil fermentasi dikeringkan selama kurang lebih tiga hari agar gas dan kadar air berkurang, kemudian ditambah 0,3\% kapur (CaCO3). Sebanyak 30 ekor cacing tanah selanjutnya ditempatkan pada permukaan media dan dibiarkan selama $2 \times 4$ jam. Media pertumbuhan sudah dapat digunakan sebagai habitat hidup cacing tanah apabila cacing tanah tidak keluar dari media atau mati. Cacing yang dipelihara dari setiap wadah adalah 30 ekor. Wadah ditempatkan pada rak-rak kayu dan ditutup dengan kertas koran agar suasananya gelap. Suhu dan kelembaban media diukur secara terus menerus agar dapat dipertahankan konstan. Penyemprotan air dilakukan dengan handsprayer setiap dua hari sekali agar kelembaban media cacing terjaga tetap. Media tumbuh cacing diaduk setiap satu minggu sekali agar aerasi berjalan baik. 
Hasil peneliitan (Prayitno, 2013) menunjukan bahwa Rasio C/N nya optimum seperti yang disyaratkan oleh Peraturan Menteri Pertanian (2011) salah satu aspek yang paling penting dari keseimbangan hara. $\mathrm{C} / \mathrm{N}$ ratio bahan organik yang menunjukkan perbandingan antara banyaknya kandungan unsur karbon dengan banyaknya kandungan nitrogen pada suatu bahan, seperi vermikompos.

\section{Hasil}

Penyampaian materi dalam kegiatan ini terdiri atas empat hal, yakni; Penyuluhan online peningkatan pengetahuan vermikompos; Peningkatan minat; Peningkatan Ketrampilan; dan Diskusi. Penyampaian materi ini dilakukan secara online dengan menggunakan platform zoom meeting. Sebelum dan setelah penyampaian materi dilakukan pre-test dan post-test sebagai bahan evaluasi keberhasilan penyuluhan.

Penyuluhan online Peningkatan Pengetahuan Vermikompos

Pengetahuan audiens tentang vermikompos untuk media tanaman melalui pertanyaaan "Apakah Bapak/Ibu memahami vermikompos?" Sebelum penyuluhan partisipan menjawab dengan angka rata-rata pre-test adalah 1,20 dari kategori jawaban 1,2,3,4,5 berturut-turut dikategorikan pada tingkat pemahaman "tidak paham, kurang paham, cukup paham, paham, dan sangat paham". Berarti pada sebelum diadakan penyuluhan kebanyakan peserta "tidak paham", harena 83,33\% dan $16,67 \%$ menjawab "kurang paham". Angka ini bisa dibaca secara terbalik, yaitu bahwa partisipan berada pada tingkat "cukup paham sampai dengan sangat paham" jumlahnya masih nol (0) persen (Tabel 1).

Tabel. 1. Tingkat Pemahaman, Minat dan Keterampilan pada pretest dan posttest Penyuluhan online tentang Vermikompos

\begin{tabular}{lrrrrrrr}
\hline & \multicolumn{2}{c}{ Pemahaman } & \multicolumn{2}{c}{ Minat } & \multicolumn{2}{c}{ Keteramilan } \\
\cline { 2 - 8 } $\begin{array}{l}\text { Penyuluhan } \\
\text { Online }\end{array}$ & \multicolumn{3}{c}{ post } & \multicolumn{2}{c}{ post } & \multicolumn{2}{l}{ pre } \\
pre test & test & pre test & test & \multicolumn{1}{c}{ test } & post test \\
\hline 1 & 83,33 & 0,00 & 75,00 & 0,00 & 83,33 & 0,00 \\
\hline 2 & 16,67 & 0,00 & 16,67 & 8,33 & 16,67 & 50,00 \\
\hline 3 & 0,00 & 25,00 & 8,33 & 25,00 & 0,00 & 50,00 \\
\hline
\end{tabular}




\begin{tabular}{lrrrrrr}
\hline 4 & 0,00 & 66,67 & 0,00 & 66,67 & 0,00 & 0,00 \\
\hline 5 & 0,00 & 8,33 & 0,00 & 0,00 & 0,00 & 0,00 \\
\hline Rata-rata & 1,20 & 3,65 & 1,20 & 3,00 & 1,20 & 3,00 \\
\hline
\end{tabular}

\section{Keterangan :}
Tingkat pemahaman $=$ (1) Tidak Paham, (2) Kurang Paham, (3) Cukup Paham, (4) Paham dan (5) Sangat Paham
Tingkat Minat $\quad=$ (1) Tidak Berminat, (2) Kurang Berminat, (3) Cukup Berminat, (4) Berminat, dan (5) Sangat Berminat.
Tingkat Keterampilan $=$ (1) Tidak Terampil, (2) Kurang Terampil, (3) Cukup Terampil, (4)Terampil, dan (5) Sangat Terampil.

Tabel. 2. Rank Evaluasi Hasil Penyuluhan Vermikompos via online.

\begin{tabular}{lllll}
\hline Rank Evaluasi Hasil Penyuluhan Online & P & M & T \\
\hline Tidak Berhasil & $\leq 1,2$ & & & \\
\hline Kurang Berhasil & $>1,2-1,96$ & & \\
\hline Cukup Berhasil & $>1,96-2,72$ & & & \\
\hline Berhasil & $>2,72-3,48$ & & $\sqrt{ }$ & $\checkmark$ \\
\hline Sangat Berhasil & $>3,48$ & $\sqrt{ }$ & & \\
\hline
\end{tabular}

Keterangan: Angka rata-rata pre-test $=1,2$. Angka maksimal dalam posttest $=5$. Beda antara pre-test dan post-test $=5-1,2=3,8$, interval $=3,8 / 5$ $=0,76 . \mathrm{P}=$ Pemahaman, $\mathrm{M}=$ Minat dan $\mathrm{T}=$ Keterampilan. 
Setelah dilakukan penyuluhan, angka post-test pada tingkat pemahaman menjadi rata-rata 3,65, dikategorikan "sangat berhasil" (Tabel 2). Ini diakibatkan hampir mendekati "paham" dengan persentase sebanyak 66,77 $\%$, dan "cukup paham" sebanyak $25 \%$, bahkan terdapat masuk kategori "sangat paham" sebanyak $8.33 \%$.

Peningkatan Minat

Masyarakat tidak hanya cukup dalam menambah pengetahuan atau pemahaman, tetapi masyarakat harus bergeser ke tahap berikutnya yakni, "apakah partisipan berminat untuk membuat vermikompos?

Minat merupakan bagian dari sikap yang merupakan kecenderungan untuk melakukan pembuatan vermikompos. Kelebihan melihat minat kepada partisipan apabila diinginkan untuk melihat partisipan apakah hanya berhenti pada bertambahnya wawasan yang salah satunya ditandai dengan bertambahnya pengetahuan dari kegiatan ini atau sudah bergeser ke arah minat dari partisipan.

Peningkatan Keterampilan

Masyarakat tidak hanya cukup dalam menambah pengetahuan/pemahaman dan berminat melakukan pembuatan vermikompos, tetapi masyarakat harus bergerak kepada tahap berikutnya pada perilaku eksternal, misalnya mulai mempraktekkan hal-hal yang bisa dilakukan dari peningkatan pengetahuan dan minat. Post-test nya dilakukan satu minggu setelah pelaksanaan, sebagai post-test dalam pelaksanaan atau keterampilan pembuatan vermikompos.

Keterampilan audiens tentang pembuatan vermikompos untuk media tanaman melalui pertanyaaan Apakah Bapak/Ibu mulai untuk membuat vermikompos? Sebelum penyuluhan partisipan menjawab dengan angka ratarata pre-test adalah 1,20 dari kategori yang sama seperti pada peningkatan pengetahuan bahwa jawaban 1,2,3,4,5 berturut-turut dikategorikan dengan modifikasi pertanyaan tingkat pemahaman dan minat, yaitu "sangat jarang, jarang, cukup sering, sering, dan sangat sering”, masuk kedalam kategori "sangat jarang". Berarti pada sebelum diadakan penyuluhan kebanyakan 
peserta "sangat jarang dan jarang" sebanyak 100,00\%. Angka ini bisa dibaca secara terbalik, yaitu bahwa partisipan berada pada tingkat "cukup minat sampai dengan sangat minat” jumlahnya mencapai 0,00 persen (Tabel 1).

\section{Diskusi}

Penyebab Peningkatan Pengetahuan

Keberhasilan ini dikarenakan salah satunya adalah karena materi mudah dipahami yang disampaikan dalam slide secara online melalui zoom. Selain itu, penyampaian materi tidak hanya mudah dipahami oleh masyarakat biasa, namun juga para audiens yang terdiri dari pelaku usaha, karyawan, konsumen, dan mahasiswa.

Budidaya tanaman dalam pot atau pada hamparan relatif baik dengan menggunakan kompos sebagai pupuk organik, apalagi jika kompos tersebut dilakukan secara vermikompos lebih mudah diserap oleh tanaman.

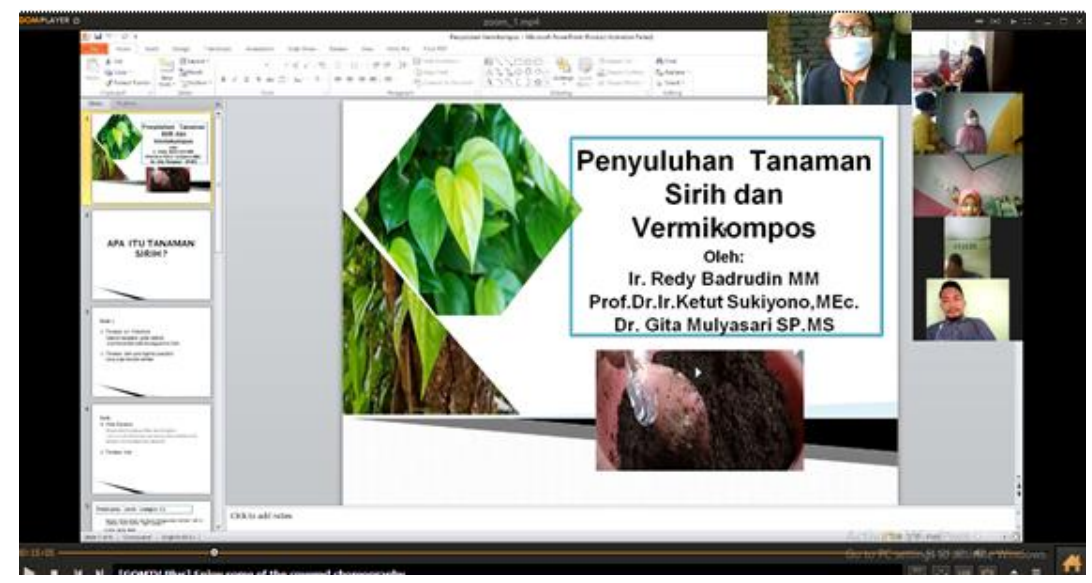

Gambar 1. Penyuluhan Online Penanaman Sirih oleh Tim Pengabdian

Bila persentasenya dihitung dari "cukup paham sampai dengan sangat paham" maka persentasenya naik menjadi 100\%. Dengan kenaikan angka rata-rata dan persentase yang meningkat pada tingkat pemahaman pengetahuan vermikompos dari " tidak paham dan kurang paham” menjadi “ "cukup paham sampai dengan sangat paham", berarti kegiatan penyuluhan vermikompos yang dilakukan dikategorikan pada "sangat berhasil" (Tabel 2). Hasil uji Fatahillah (2017) pada penambahan berbagai dosis vermikompos 
cacing (Lumbricus rubellus) terhadap pertumbuhan vegetatif dalam tanaman pot menunjukkan bahwa pemberian vermikompos pada media tanam memberikan pengaruh yang nyata terhadap pertumbuhan tinggi tanaman, jumlah daun, luas daun, diameter batang dan jumlah cabang tanaman. Pembuatan pupuk dari sampah (jerami) juga diperkenalkan oleh Wahyuni \& Yani (2019) melalui metode pembelajaran dan sosialisasi berdasarkan tingkat pengetahuan dan keterampilan petani dapat dijadikan usaha oleh petani dalam meningkatkan usaha tani. Selanjutnya Sihaloho dkk (2015) dan Suparno dkk (2013) mengemukakan bahwa hasil penelitian mereka menunjukkan bahwa pemberian vermikompos pada tanaman berpengaruh nyata. Hasilnya tingkat pengetahuan petani tentang pupuk organik termasuk kategori berpengetahuan sedang, peningkatan pengetahuan masyarakat dianalisis berdasarkan hasil ujian pada pre-test dan post-test.

\section{Alasan Peningkatan Minat}

Dengan kenaikan angka rata-rata dan persentase yang meningkat pada tingkat minat pada pembuatan vermikompos dari "tidak berminat dan kurang minat" menjadi "cukup berminat sampai dengan sangat berminat." Kegiatan penyuluhan vermikompos yang dikategorikan berhasil (Tabel 2), dalam menaikan minat peserta penyuluhan online.

Setelah dilakukan penyuluhan, angka post-test pada tingkat pemahaman menjadi menjadi rata-rata 3,00, dikategorikan "berhasil" (Tabel 2). Ini disebabkan partisipan "berminat" dengan persentase sebanyak 66,77\%, dan "cukup berminat" sebanyak 25\%, bahkan terdapat masuk kategori "sangat berminat" sebanyak $8,33 \%$. Bila persentasenya dihitung dari "cukup berminat sampai dengan sangat berminat" maka persentasenya naik menjadi $100 \%$.

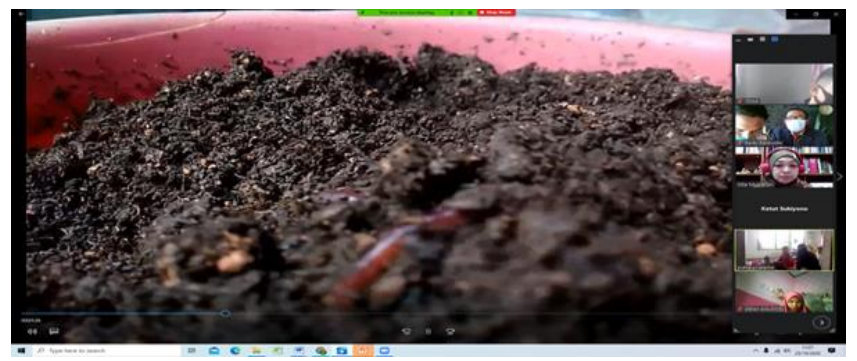

Gambar 2. Penyuluhan online Vermikompos oleh Tim Pengabdian 
Alasan terjadinya keberhasilan ini dikarenakan salah satunya materi mudah dipahami, disampaikan dalam slide secara online melalui zoom tetapi juga adanya video (Gambar 2). Budi daya tanaman dalam pot atau pada hamparan relatif baik dengan menggunakan kompos sebagai pupuk organik, apalagi jika kompos tersebut dilakukan secara vermikompos lebih mudah diserap oleh tanaman. Tentunya pemahaman ini kesadaran masyarakat terhadap penggunaan vermikompos sebagai alternatif penggunaan pupuk dalam pot.

\section{Motif Mulai Terjadinya Peningkatan Keterampilan}

Setelah dilakukan penyuluhan, angka post-test pada tingkat keterampilan menjadi rata-rata 3,00, atau "cukup sering", mengindikasikan kegiatan penyuluhan melalui online "berhasil" (Tabel 2). Ini dikarenakan partisipan memiliki persentase tingkat keterampilan "cukup terampil sampai dengan sangat terampil sebanyak $50 \%$ dan sisanya "jarang dan sangat jarang". Ini sejalan dengan Pengalaman Wardana dkk (2017) melaporkan bawa keterampilan petani terhadap pupuk organik petani di Subak Anyar Sidembunut termasuk kategori baik atau berhasil.

Motif keberhasilan ini dikarenakan salah satunya materi mudah dipahami, disampaikan dalam slide secara online melalui zoom meeting dan adanya video dan kunjungan rutin, ditambah dengan kemungkinan bertambahnya peluang bisnis alternatif yang berakibat pada naiknya keterampilan. Bagi keluarga yang memiliki sapi sudah mulai membuat vermikompos dari kotoran sapi dan bagi yang tidak punya hewan peliharaan membeli kompos di depot dan atau sampah rumah tangga untuk dijadikan vermikompos. Harga kompos Rp15.000,00 per karung, dan vermikompos Rp30.000,00.

Selama pandemi covid-19, alternatif penjualan pupuk vermikompos dari kotoran sapi dapat menghasilkan Rp900.000,00 sampai dengan Rp1.200,000,00 atau yang berasal dari 30 sampai 40 kantong pupuk. Hasil dari pupuk ini diperoleh melalui kotoran dua sapi dewasa dan satu anak sapi. Sebelum pandemi, pendapatan untuk jumlah kantong yang sama hanya 
berkisar Rp440.000,00 sampai dengan Rp600,000,00. Perbedaan penghasilan vermikompos ini dapat dijadikan alternatif penerimaan agar masyarakat bertahan selama pandemi covid-19.

\section{Kesimpulan}

Kesimpulan dari pengabdian ini yang pelaksanaannya melalui online telah terjadi peningkatan pengetahuan, minat, dan keterampilan dalam hal pembuatan vermin kompos bagi klaster komoditas warung jajanan (KKWJ) tidak hanya sebagai strategi bertahan pada era ketidakpastian tetapi juga sebagai persiapan strategi diversifikasi memasarkan produk baru berupa vermikompos dan pasar baru pada saat yang ditunggu-tunggu yaitu datangnya era ketidakpastian. Dari hasil dan diskusi di atas menghasilkan rekomendasi bahwa bagi kegiatan pertanian urban seperti yang dilakukan oleh KKWJ dapat memperkecil risiko bisnis dengan menjadikan pembuatan vermikompos sebagai bisnis tambahan selain bisnis utamanya.

\section{Pengakuan/Acknowledgements}

Ucapan terima kasih disampaikan kepada: (1) Dr. Ir. Dwi Wahyuni Ganefianti, M.S, Selaku Dekan Fakultas pertanian atas diberikannya kesempatan kepada kami untuk melakukan pengabdian Fakultas Pertanian Universitas Bengkulu dengan kontrak Nomor 2355/UN30.11/PM/2020, (2) Tim Pendamping Koldi Sudiansyah, Putra Pratama Yuliansyah, dan Tomi, (3) Ibu Poniem, karyawan dan tetangga beliau sebagai yang dituakan dari kelompok warung jajanan sekitar Unib, (4). Para konsumen warung jajanan, yaitu para mahasiswa, (5) Bapak Edi Masito, SE MM sebagai Ketua RT RT 17 RW 02 Kelurahan Pematang Gubernur Kecamatan Rawa Makmur Kota Bengkulu atas izinnya untuk melaksanakan pengabdian secara online melalui zoom meeting.

\section{Daftar Referensi}

Ariesanti, Y., Sandra, F., Astuti, L., Lubis, M. N. P., \& SPR, I. S. (2021). Pemberdayaan Masyarakat Dalam Meningkatkan Kesehatan Dan Mencegah Infeksi Rongga Mulut Selama Pandemi Covid-19. Jurnal Abdi Masyarakat Indonesia, 3(1). 
BPS. (2020). Laju Pertumbuhan PDRB menurut Pengeluaran (Persen), 2020. Badan Pusat

Statistik.

https://bengkulu.bps.go.id/indicator/52/213/2/laju-pertumbuhan-pdrbmenurut-pengeluaran.html

Brata, B. (2017). Pengaruh Beberapa Campuran Media pada Feses Sapi Kaur yang Diberi Pakan Rumput Setaria dan Pelepah Sawit terhadap Biomassa dan Kualitas Vermikompos Cacing Tanah Pheretima sp. Jurnal Sain Peternakan Indonesia, 12(2), 142-151.

Estupinan, X., \& Sharma, M. (2020). Job and Wage Losses in Informal Sector due to the COVID-19 Lockdown Measures in India. Available at SSRN 3680379.

Fatahillah, F. (2017). Uji Penambahan Berbagai Dosis Vermikompos Cacing (Lumbricus Rubellus) Terhadap Pertumbuhan Vegetatif Cabai Rawit (Capsicum Frutescens L.). Jurnal Biotek, 5(2), 191-204.

Kementerian Pertanian. (2011). Permen Nomor 70/Permentan/Sr.140/10/2011 Tentang Pupuk Organik, Pupuk Hayati Dan Pembenah Tanah. Jakarta.

Lazcano, C., \& Domínguez, J. (2011). The use of vermicompost in sustainable agriculture: impact on plant growth and soil fertility. Soil Nutrients, 10(1-23), 187.

Mujiyo, M., \& Suryono, S. (n.d.). Pemanfaatan Kotoran Kambing Pada Budidaya Tanaman Buah Dalam Pot Untuk Mendukung Perkembangan Pondok Pesantren. PRIMA: Journal of Community Empowering and Services, 1(1), 5-10.

Nusantara, A. D., Kusmana, C., Mansur, I., Darusman, L. K., \& Soedarmadi, S. (2010). Pemanfaatan Vermikompos Untuk Produksi Biomassa Legum Penutup Tanah Dan Inokulum Fungi Mikoriza Arbuskula. Jurnal IlmuIlmu Pertanian Indonesia, 12(1), 26-33.

Prayitno, P. (2013). Pembuatan vermikompos menggunakan limbah fleshing di industri penyamakan kulit. Majalah Kulit, Karet, Dan Plastik, 29(2), 77-84.

Putra, A. R. D., Mardiyani, S. A., \& Nurhidayati, N. (2020). Peran Vermikompos terhadap Morfofisiologi Kangkung Hidroganik. Agrotechnology Research Journal, 4(2), 70-76.

Putrianingsih, Y., \& Dewi, Y. S. (2019). Pengaruh Tanaman Sirih Gading (Epipremnum aureum) Terhadap Polutan Udara Dalam Ruangan. Jurnal TechLINK Vol, 3(1).

Sihaloho, N. S., Rahmawati, N., \& Putri, L. A. P. (2015). Respons pertumbuhan dan produksi tanaman kedelai varietas Detam 1 terhadap pemberian vermikompos dan pupuk P. Jurnal Agroekoteknologi 
Universitas Sumatera Utara, 3(4), 106663.

Suparno, S., Prasetya, B., Talkah, A., \& Soemarno, S. (2013). Aplikasi

Vermikompos Dalam Usahatani Sawi Organik Di Kediri, Indonesia. The Indonesian Green Technology Journal, 2(2), 78-83.

Suranjaya, I. G., Kartini, N. L., Purnawan, N. L. R., \& Suardana, P. E. (2019).

Vermikompos Sampah Tanaman Gulma Danau Menggunakan

Decomposer Cacing Tanah Untuk Menghasilkan Pupuk Organik. Buletin Udayana Mengabdi, 18(1).

Wahyuni, S., \& Yani, F. (2019). Pemanfaatan Jerami Sebagai Bahan Baku Pembuatan Pupuk Organik Di Desa Pematang Johar Kecamatan Labuhan Deli Kabupaten Deli Serdang. Prosiding Seminar Nasional Hasil Pengabdian, 2(1), 573-576.

Wardana, I. G. N. W., Tariningsih, D., \& Lestari, P. F. K. (2017). Pengetahuan dan Keterampilan Petani terhadap Pupuk Organik pada USAhatani Padi Sawah (Studi Kasus di Subak Anyar Sidembunut, Desa Cempaga, Kecamatan Bangli, Kabupaten Bangli). Jurnal Agrimeta, 7(13). 